S3 Table. Comments value functions. For each value function that was elicited from the river experts, we give the attribute name and abbreviation (used in the later analyses), and details concerning the attribute or shape of the value function. Also see S2 Table.

\begin{tabular}{lll}
\hline \hline Attribute & Abbreviation & Comments \\
\hline $\begin{array}{l}\text { Sediment } \\
\text { transport }\end{array}$ & sedtrans & $\begin{array}{l}\text { Sediment transport is easier to measure in meandering than in braided rivers. It is measured with topographical surveys of the river profile, and } \\
\text { is an important monitoring measure in practice. It is usually measured all five years. The volume balance is calculated from the river profile } \\
\text { and distributed in the measurement period (i.e. five yrs.). The measures are not exact; one can easily have deviations up to } \pm 100 \% . \text { A problem } \\
\text { is the definition of the natural state (reference). Values depend on the river; our expert was only familiar with the river Sihl and gave a value }\end{array}$
\end{tabular}
function for this river (origin near Einsiedeln and flows into lake Zürich).

Diversity of patchdiv-L Phys was not able to give the shape of the value function; he would probably use Sigma (= root of (D16/ D84), where D16 = 16\% of granules patches of are smaller than $\mathrm{xy} \mathrm{cm}$ diameter, and $\mathrm{D} 84=84 \%$ of granules are smaller than $\mathrm{xz} \mathrm{cm}$ diameter). One has a composition of the substrate from 0 river bed to $20 \mathrm{~cm}$ diameter and determines the relative weight of each component. This number gets larger, the wider the substrate distribution. It is (coarse therefore a function of the slope: a steep river has a much higher number than a level river. In a worst-possible case, sigma would be 1 , a good natural case, sigma $=6$.

substrate)

Another very good attribute, according to Phys, is to use LAWA classes. For this, one first needs to know the river type and whether it has fine or coarse substrate (coarse substrate for the Wigger). One assigns the river to one of seven classes (class 1: very large diversity of substrate, class 2: large, class 4: moderate, class 5: low, class 7: no diversity of substrate). These classes were treated as discrete and translated to values according to Langhans et al. (2013). Details see separate section in Supplementary Data.

Total sinuos One has to distinguish between braided and meandering rivers. The attribute is: "sum of the length of all river arms of river section (following sinuosity all braids)/ (straight) length of the river section". The value function must be steep for the lower values, because an improvement when the (braided

rivers) river is in a bad state is very valuable, while the gain of additional braids, once there are some braids, is not so large.

Relation depthveloc
For meandering rivers one has the same shape of the curve, but the range is from 1 (= minimum) to 1.8 (= maximum) for a Wigger-type river.

Relation

depthveloc

depth and

velocity

One measures the depth and the velocity at several (e.g. 100) cross-sections of the river. For each cross section, the Froude number is calculated: $\mathrm{Fr}=\mathrm{v} / \mathrm{sqrt}(\mathrm{g} \times \mathrm{h})$, where $\mathrm{v}=$ velocity, $\mathrm{g}=$ acceleration, $\mathrm{h}=$ water depth. The diversity of the Froude numbers is then measured with a diversity index such as the Shannon Weaver index and compared to a reference river. The higher the diversity, the better the value; BioPhys gave relative values and postulated that this is a linear relationship for the Shannon Weaver index $H^{\prime}$, where $S$ is the total number of species and $p_{i}$ is the frequency of the $i^{\mathrm{h}}{ }^{\mathrm{s}}$ species (the probability that any given individual belongs to the species, hence $\mathrm{p}$ ).

distribution $H^{\prime}=-\sum_{i=1}^{S}\left(p_{i} \ln p_{i}\right)$

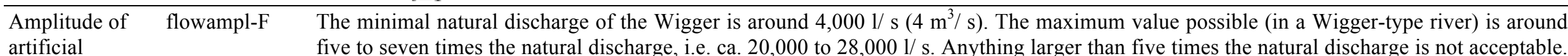
artificial

flow

variation

Amplitude of artificial There is a linear relationship in between. In larger rivers, the values can be quite different, and in extreme cases, it can be 20 to 30 times the natural discharge.

flowampl-BP If there is a hydropower plant in the river, it creates daily amplitude of the discharge. The most common indicator in Switzerland is the ratio between the high and low discharge during one day, where factor eight is an extreme worst case, and one the natural best case. In the EU this 


\begin{tabular}{|c|c|c|}
\hline Attribute & Abbreviation & Comments \\
\hline $\begin{array}{l}\text { flow } \\
\text { variation }\end{array}$ & & $\begin{array}{l}\text { indicator is called the maintenance flow regime (and not the natural flow regime) with the idea to restrict the range of small hydro-electrical } \\
\text { plants. Amplitude of artificial flow variation = (high flow during the day in } \mathrm{m}^{3} / \mathrm{s} \text { ) / (low flow during the day in } \mathrm{m}^{3} / \mathrm{s} \text { ). }\end{array}$ \\
\hline $\begin{array}{l}\text { Rate of } \\
\text { decrease of } \\
\text { artificial } \\
\text { flow } \\
\text { variation }\end{array}$ & flowrate & $\begin{array}{l}\text { This is an indicator of daily storage of water due to a hydropower plant and hydropeaking. It measures whether the water level falls very } \\
\text { steeply. The increase is not important, but for the decrease, speed can be a problem. The values given are for the river Saane, which is about } \\
\text { the worst artificial flow variation one can have in Switzerland. The minimum (worst-possible case) is around } 40 \mathrm{~cm} / \mathrm{h} \text { to } 200 \mathrm{~cm} / \mathrm{h} \text {, the best } \\
\text { case around } 10 \mathrm{~cm} / \mathrm{h} \text {. }\end{array}$ \\
\hline $\begin{array}{l}\text { Maximal } \\
\text { discharge }\end{array}$ & dischav & $\begin{array}{l}\text { For each of the four seasons the discharge is measured; the maximal value from the four seasons is taken and compared with a reference } \\
\text { river: } \% \text { deviation of discharge from reference river }=100-((\text { max. discharge of river) } \mathrm{x} 100 / \text { (natural discharge of reference river) }) .100 \% \\
\text { deviation means that there is no flow, } 0 \% \text { that the river is in its natural state. One could also calculate } \% \text { deviation of discharge separately for } \\
\text { each season and then average over all } 4 \text { seasons. }\end{array}$ \\
\hline $\begin{array}{l}5^{\text {th }} \text { percentile } \\
\text { of discharge } \\
\text { distribution }\end{array}$ & dischdist & $\begin{array}{l}\text { The } 5^{\text {th }} \text { percentile of discharge distribution is the discharge which is exceeded in } 95 \% \text { of the days. It is an indicator for seasonal storage; i.e. if } \\
\text { there are dams in the river which are operated on a yearly regime, where water is kept back in the summer. It is compared to a reference river: } \% \\
\text { deviation of } 5^{\text {th }} \text { percentile of discharge distribution from reference river }=100-\left(\left(5^{\text {th }} \text { percentile of discharge distribution of river) } x 100 /(\text { natural }\right.\right. \\
\left.\left.5^{\text {th }} \text { percentile of discharge distribution of reference river }\right)\right) .0 \% \text { means that the } 5^{\text {th }} \text { percentile discharge distribution is the same as in the (natural) } \\
\text { reference river. }\end{array}$ \\
\hline $\begin{array}{l}\text { Discharge of } \\
\text { annual flood }\end{array}$ & flooddisch & $\begin{array}{l}\text { The annual flood is the highest flood which occurs on average once a year (higher floods are possible, but less frequent). One compares the } \\
\text { discharge value of the annual flood with a reference river: } \% \text { deviation of discharge of annual flood from reference river }=100-((\text { discharge } \\
\text { of annual flood of river) x } 100 / \text { (natural annual flood discharge of reference river) }) .100 \% \text { deviation means that there is no annual flood, } 0 \% \\
\text { that the river is in its natural state. For a general case, a linear relationship is a good approximation, but for more-detailed cases, one would } \\
\text { have to introduce two to three thresholds that specify the start of different process and model the relationship between geomorphological and } \\
\text { ecological processes. }\end{array}$ \\
\hline $\begin{array}{l}\text { Frequency of } \\
\text { bed-moving } \\
\text { flood }\end{array}$ & floodbed-BP & $\begin{array}{l}\text { Compare the average size of the substrate with the size of the substrate of the reference system: \% deviation of frequency of bed-moving flood } \\
\text { from reference river }=100-((\text { frequency of bed-moving flood) } \times 100 / \text { (natural frequency of bed-moving flood of reference river)). } 0 \% \text { deviation } \\
\text { means that the substrate size of the river is the same as in the (natural) reference river. }\end{array}$ \\
\hline $\begin{array}{l}\text { Frequency of } \\
\text { bed-moving } \\
\text { flood }\end{array}$ & floodbed-P & $\begin{array}{l}\text { The minimum is } \mathrm{HQ}_{20}=\text { statistically a river-bed forming discharge (i.e. large flood) every } 20 \text { years. There is an optimum at around one flood } \\
\text { every three to five years. }\end{array}$ \\
\hline $\begin{array}{l}\text { Frequency of } \\
\text { floodplain } \\
\text { flooding }\end{array}$ & floodplain-BP & $\begin{array}{l}\text { Compare the frequency of floodplain floodings with those in a reference system: \% deviation of frequency of floodplain flooding from reference } \\
\text { river }=100-((\text { frequency of floodplain flooding) x } 100 / \text { (natural frequency of floodplain flooding of reference river)). } 0 \% \text { deviation means that } \\
\text { the floodplain flooding of the river is the same as for the (natural) reference river. }\end{array}$ \\
\hline $\begin{array}{l}\text { Frequency of } \\
\text { floodplain } \\
\text { flooding }\end{array}$ & floodplain-L & $\begin{array}{l}\text { According to LAWA (2004), the frequency of floodplain inundations that are at least two times as large as the river width are assessed in seven } \\
\text { classes (class } 1 \text { : natural = flooding every one - two years, class 3: impaired = every three - five yrs., class } 7: \text { strongly reduced = floodings } \\
\text { fewer than every five yrs.). These classes were transformed into a continuous value function according to Langhans et al. (2013). Further details } \\
\text { see separate section in Supporting Information. }\end{array}$ \\
\hline
\end{tabular}




\begin{tabular}{lll}
\hline \hline Attribute & Abbreviation & Comments \\
\hline $\begin{array}{l}\text { Height of } \\
\text { artificial }\end{array}$ & barrheight & This value function describes barriers for all fish species, including small fish. Fish are the most important taxa for which barriers should be \\
barriers & & $\begin{array}{l}\text { assessed; other species can often pass them, e.g. insects can fly. The barriers can be any artificial obstacles (weirs, but also missing or inadequate } \\
\text { fish ladders if there are power stations). The value function is linear, because the Fish-expert does not have any good argument for another } \\
\text { (barriers for }\end{array}$ \\
mix of fish
\end{tabular}
mix of fish species)

No power

For this value function the Fish-expert assumed that the power stations have fish passes (this is the case for newer power stations). So fishes can pass the obstacle upstream. However, when they wander down the river, they often get killed, e.g. in turbines. The mortality can be anywhere between $10-90 \%$. As example, assuming a mortality rate of $10 \%$, with three power stations, the rate would be $10 \% \times 3=30 \%$. The value function certainly has an exponential decrease, but the exact numbers are very dependent on the length of the fish, the power station, the size of the turbine etc. So the given value function is just a best guess. Note, the Wigger has a small power station without a fish pass.

\section{Fraction of ripbank}

natural river

banks

Relative

shoreline

length only

straight and

braided river

Total width

between

levees and

river

Incision

This attribute is required for braided and straight rivers, but not for meandering rivers. The shape of the curve must be asymptotic, but the maximum can depend on the measurement method. The minimum (worst value) is two because there are two banks.

leveeswidth If there are levees, the functioning of the river system can be impaired compared to the river being able to flow freely over the total width of the "natural" floodplain. The relationship must be an asymptotic curve so that an improvement when the river is in a bad state is of higher value than improvements if the river is already in a good state. BioPhys was only able to give relative values between 0 and 1.

incision

The depth of incision is measured from the old stream bed, which can be seen on the margins of the river, to the bottom of today's riverbed. If there is a strong incision, the water during a flood cannot leave the channel. The curve is not linear. If incision starts, this is an indication that something is going really wrong. Once incision has started, it can go on "forever". So the value decreases strongly at the beginning. In Switzerland, in a normal river, the worst case is ca. four to five meters.

Substrate substrclog-L According to Schälchli (2002), the colmation is assessed in five classes (no colmation: substrate very loose and coarsely granular / weak clogging colmation: substrate loose and broadly tiered / medium colmation: substrate slightly cemented / strong colmation: substrate is clearly cemented / total colmation: substrate is strongly cemented). These classes were transformed into discrete values according to Langhans et al. (2013). For details see separate section in Supplementary Data. of the curve has to be sigmoid; the Phys-expert gave relative values of sigma. D16 means that $16 \%$ of the granulas are smaller than xy cm in Kolmation) diameter, and D84 that $84 \%$ are smaller than xz diameter. Near the maximum, the curve has to be very flat. The worst-possible case is $1=$ everything consists of the same material. 


\begin{tabular}{|c|c|c|}
\hline Attribute & Abbreviation & Comments \\
\hline $\begin{array}{l}\text { Vertical } \\
\text { hydrological } \\
\text { exchange }\end{array}$ & hydrex & $\begin{array}{l}\text { This is a direct measure; there are various ways to measure it: tracers, piezo-meter, mapping of the hydraulic head, or sampling the radon } \\
\text { concentration in the sub-surface compartment. The easiest way is to sample radon, but a lab is required that can do these analyses (available at } \\
\text { Eawag). BioPhys suggests to compare the exchange in the river with a reference river that is still "natural" and that is similar with respect to } \\
\text { geomorphology and substrate. The worst case (minimum) cannot be zero, because there are always some hydrological exchange processes } \\
\text { going on. The shape of the curve has to be asymptotic with a steep increase in the beginning, because some exchange, if the river is in a poor } \\
\text { state, is very important. }\end{array}$ \\
\hline
\end{tabular}

Maximal temperature

in summer

Seasonally averaged temperature

Absolute maximal temperature small river Spatial temperature distribution small river

\section{Daily}

amplitude

small river

Gradient / slope of

heating tempsummax very important.

According to the Fish-expert it is sufficient to take the maximal temperature in summer as attribute; no others are required for "natural temperature regime" (apart from maybe daily amplitude if there is hydropeaking). One has to distinguish between head waters and mid-/ lower reaches, but the values are similar. The maximum the Fish-expert ever measured in the Wigger was $23^{\circ} \mathrm{C}$ and it is highly unlikely that it would ever become warmer than $24^{\circ} \mathrm{C}$ (for other rivers, such as the Thur, warmer temperatures are possible). In summer, in the mid- and lower reaches, the minimum would be around $12-13^{\circ} \mathrm{C}$ (= best-possible case). The value function was derived based on the growth-optimum for trout, which is $7-17^{\circ} \mathrm{C}$ (juveniles: max. $14^{\circ} \mathrm{C}$ ). Hence, good values $(1)$ are from $10-17^{\circ} \mathrm{C}$ in summer, then there is a linear decrease, and from temperatures higher than $20^{\circ} \mathrm{C}$ the value is 0 (worst-possible state), because trout growth is impaired.

tempav BioPhys suggests comparing the average temperature of the river (which can be measured in one spot) with the average temperature of a reference river. As reference river, choose a river that is still braided (or meandering). Even under climate change, this best-possible system will have cooler temperatures than a strongly channelized river, or one that is used to cool the water from a nuclear power plant. Maximum deviation of temperature from reference river $=\left(\max\right.$. temperature of river)/ (average temperature of river). The worst-possible case is $15^{\circ} \mathrm{C}$ per season, i.e. that the average temperature of the impacted river is e.g. $25^{\circ} \mathrm{C}$, while that of the reference river is $10^{\circ} \mathrm{C}$. The Fish-expert states that this attribute is not at all important; the average temperature does not give much information.

tempmax This is an indicator of extreme events and of heat waves. The absolute maximum temperature that was ever measured in the river is compared to a reference river. The worst case for a small river such as the Wigger is $11.25^{\circ} \mathrm{C}$ deviation from a reference river.

tempdistr

The spatial temperature distribution is the maximal degree of difference in the temperature between different plots in the river. It is measured during the warmest part of the day and is an indicator of whether there are cool water refugia. The relationship is a sigmoid curve. the maximal (best) value for a small river such as the Wigger is $5^{\circ} \mathrm{C}$, for a medium-sized river $7^{\circ} \mathrm{C}$, and for a large river (e.g. river Thur in Switzerland) $\left.10^{\circ} \mathrm{C}\right)$.

amplday

Deviation of daily amplitude $=($ maximal temperature of river per day - minimal temperature of river per day $)-($ maximal temperature of reference river per day - minimal temperature of reference river per day). There is a linear relationship. In small rivers, the normal amplitude can be around $10^{\circ} \mathrm{C}$, in large rivers it is less; ca. $2-3^{\circ} \mathrm{C}$ (in summer). Worst case for small river (e.g. Wigger): $20^{\circ} \mathrm{C}$, medium-sized river: $15^{\circ} \mathrm{C}$, large river (e.g. river Thur in Switzerland): $5^{\circ} \mathrm{C}$. Best case is always 0 deviation from reference.

heatslope The gradient (slope) of heating $=$ is the increase in temperature in ${ }^{\circ} \mathrm{C}$ per hour. It is compared to a reference river. In a natural reference river, one would have $5^{\circ} \mathrm{C}$ as gradient of heating, while an impacted river can have in an extreme case $7^{\circ} \mathrm{C}$. The maximal difference that BioPhys ever measured was $2^{\circ} \mathrm{C}$ heating per hour more than in a natural river. The temperature should be measured in different spots (i.e. also over space, not only time). 
Langhans SD, Lienert J (2016) Non-valid MCDA Simplifications. Plos One Supporting Information.

\begin{tabular}{|c|c|c|}
\hline Attribute & Abbreviation & Comments \\
\hline $\begin{array}{l}\text { Gradient / } \\
\text { slope of } \\
\text { cooling }\end{array}$ & coolslope & $\begin{array}{l}\text { As for the gradient (slope) of heating. The values are similar: the worst case is } 2^{\circ} \mathrm{C} \text { difference to reference river under normal conditions, i.e. } \\
\text { excluding rain events. The temperature should be measured in different spots (i.e. also over space, not only time). }\end{array}$ \\
\hline $\begin{array}{l}\text { Total } \\
\text { suspended } \\
\text { solids }\end{array}$ & sussolidtot-L & $\begin{array}{l}\text { The value function for total suspended solids was derived from the literature: Strager et al. (2000), USEPA (2003), and own assumptions. See } \\
\text { separate section. }\end{array}$ \\
\hline $\begin{array}{l}\text { Mean } \\
\text { suspended } \\
\text { solids } \\
\text { concentratio } \\
\mathrm{n} \text { at low } \\
\text { discharge }\end{array}$ & sussolidlow & $\begin{array}{l}\text { Suspended solids concentration is measured at low discharge because of hydropower. The suspended solids are measured with a cone-like } \\
\text { device, into which } 3-4 \text { liters of water are filled. The weight of the sediment is measured. BioPhys cannot give numbers for this attribute. }\end{array}$ \\
\hline $\begin{array}{l}\text { Deposition } \\
\text { of solids in } \\
\text { floodplain }\end{array}$ & sussoliddep & \\
\hline $\begin{array}{l}\text { Water } \\
\text { quality }\end{array}$ & watqual & $\begin{array}{l}\text { Since we had explicitly excluded the entire branch "good water quality", but included this objective in our analyses, we assumed linearity for } \\
\text { the value function of the corresponding "attribute" (see text). }\end{array}$ \\
\hline $\begin{array}{l}\text { Mean } \\
\text { ecosystem } \\
\text { respiration, } \\
\mathrm{R} \text { (spring) }\end{array}$ & $\begin{array}{l}\text { respirspr } \\
\text { (respirsu, } \\
\text { respirfa) }\end{array}$ & $\begin{array}{l}\text { Respiration is measured as } \mathrm{g} \mathrm{O}_{2} /\left(\mathrm{m}^{2} \mathrm{~d}\right) \text {. The value function is a Gaussian curve, but with different values for spring, summer, and fall. It is } \\
\text { measured together with respiration (same comment for summer and fall). }\end{array}$ \\
\hline $\begin{array}{l}\text { Mean } \\
\text { primary } \\
\text { production, } \mathrm{P} \\
\text { (spring) }\end{array}$ & $\begin{array}{l}\text { prodspr } \\
\text { (prodsu, } \\
\text { prodfa) }\end{array}$ & $\begin{array}{l}\text { Production is measured as } \mathrm{g} \mathrm{O}_{2} /\left(\mathrm{m}^{2} \mathrm{~d}\right) \text {, the minimum is } 0 \text { and the maximum for a river-type river } 10 \mathrm{~g} \mathrm{O}_{2} /\left(\mathrm{m}^{2} \mathrm{~d}\right) \text {; both are indicative of a bad } \\
\text { state of the river. It is an optimum curve, with different values for spring (before leaf emergence) than for summer and fall. Production can } \\
\text { change a lot, even every } 100 \mathrm{~m} \text { in the river. It cannot be used alone, but must be combined with respiration to evaluate how the ecosystem is } \\
\text { changing. Usually one uses the ratio of production and respiration. The values depend on the problem in the river. As example, if you have the } \\
\text { problem of organic pollution and install a wastewater treatment plant, you will see a decrease - but not necessarily if the river is suffering from } \\
\text { additional impacts. If the river is shaded by trees along the shore, and maybe islands and has a longer channel length, production could be } \\
\text { lower in a Wigger-type river than it is today. If the production/ respiration values are known before the restoration, the values after restoration } \\
\text { can be compared to measure the success of the measure (same comment for summer and fall). }\end{array}$ \\
\hline $\begin{array}{l}\text { Density of } \\
\text { thermal } \\
\text { refugia }\end{array}$ & refug-BP & $\begin{array}{l}\text { To define the thermal refugia, the system is mapped with a thermal camera (infrared camera). Refugia is a place with a significant drop in the } \\
\text { temperature, e.g. } 2-3^{\circ} \mathrm{C} \text { lower than the maximal temperature. If the river is really homogenous, the river is in the worst-possible state }(=0 \% \\
\text { thermal refugia). The maximal density of thermal refugia in a natural system would be } 30 \text { to } 35 \% \text {; and up to } 40 \% \text { in extremely good conditions. } \\
\text { The curve is asymptotic. }\end{array}$ \\
\hline
\end{tabular}




\begin{tabular}{|c|c|c|}
\hline Attribute & Abbreviation & Comments \\
\hline $\begin{array}{l}\text { Density of } \\
\text { thermal } \\
\text { refugia }\end{array}$ & refug-BB & $\begin{array}{l}\text { Thermal refugia are important, as example for fish, additionally to the structural diversity which also offers refugia. BioB gave a value function, } \\
\text { but felt unsure about it and suggested that we use the one from BioPhys for our further analyses. }\end{array}$ \\
\hline $\begin{array}{l}\text { Proportion } \\
\text { shoreline } \\
\text { length/ } \\
\text { channel }\end{array}$ & shorelength-BP & $\begin{array}{l}\text { The maximum depends on the scale that you are measuring. Islands and backwaters in the river can add a lot. It is also important to note that } \\
\text { this changes with water depth. To compare the river after restoration with before, you have to compare it under the same conditions, i.e. same } \\
\text { water depth. The minimum is } 2 \text { (for the two river margins), the maximum around } 60 \text { for a Wigger-type river. Note that BioB and BioC gave } \\
\text { totally different values for the maximum. }\end{array}$ \\
\hline
\end{tabular}

length

Proportion

shoreline

length/

channel

length

shorelength-BB BioB postulates that the shape of the value function is sigmoid. After some discussion, we decided to take a literature value for the Tagliamento river as best-possible case: "Shoreline lengths ranged from $28 \mathrm{~m} \mathrm{ha}^{-1}\left(2.1 \mathrm{~km} \mathrm{~km}^{-1}\right)$ to $214 \mathrm{~m} \mathrm{ha}^{-1}\left(16.3 \mathrm{~km} \mathrm{~km}^{-1}\right)$ in the bar-braided reach. (...) Shoreline length in the island-braided reach showed a similar range. The minimum value of $37 \mathrm{~m} \mathrm{ha}^{-1}\left(3.0 \mathrm{~km} \mathrm{~km}^{-1}\right) \mathrm{occurred}^{-1}$ complete active floodplain inundation. The maximum of $212 \mathrm{~m} \mathrm{ha}^{-1}\left(17.3 \mathrm{~km} \mathrm{~km}^{-1}\right)$ occurred at water levels of between 1.0 and $1.65 \mathrm{~m}$ (van der Nat et al., 2002). Hence, BioB chose $17 \mathrm{~km} \mathrm{~km}^{-1}$ as maximal (best-possible) state. Note that BioPhys and BioC gave totally different values for the maximum.

Proportion

shoreline

length/

channel

length

Proportion

natural

tributaries

per river

length

Proportion

natural

tributaries

per river

length

Proportion

natural

tributaries

per river

length

shorelength-BC The worst-possible case, i.e. if the river is totally straight, is two (because there are two margins of the shores), the best-possible case for this type of river around four. BioC likes this attribute, because it is easy to assess, there are good numbers available, and it is a good indicator. The shape of the value function is sigmoid, but fairly flat. Note that BioPhys and BioB gave totally different values for the maximum.

tributar-BP This is very case-specific and also depends on tributaries for which species. If tributaries are mainly for fish, they have to have a certain size (example Wigger: at least $1.5 \mathrm{~m}$ wide and flow during three months/ yr). BioPhys cannot give concrete numbers and postulates that it is a linear relationship.

One has to define how many tributaries one would expect per river length to be there in a "best-possible", natural state of the river; then one has to define, how many of the existing tributaries are in a natural state. BioB postulates that the value function is linear, but steeper until the value of 0.8 is reached ( $50 \%$ natural tributaries) and then it flattens out.

One classifies the tributaries according to their morphology and calculates the proportion tributaries that are in a natural state. The shape of the value function depends on the river. Because rehabilitation measures are usually more downstream, the value function was given for lower reaches. It is a sigmoid relationship, and it is OK to put the turning point into the middle, i.e. with $50 \%$ of the tributaries being in a natural state, $50 \%$ of the objective is achieved. The shape of the curve is arguable; BioC would not make it too steep. 


\begin{tabular}{lll}
\hline \hline Attribute & Abbreviation & Comments \\
\hline Refugia: & structdiv & $\begin{array}{l}\text { Shading and refugia are important aspects of structural diversity, additionally to thermal refugia. This is not covered by the hydromorphological } \\
\text { structural }\end{array}$ \\
diversity & $\begin{array}{l}\text { attributes such as the relationship between depth and velocity distribution. 100\% structural diversity is achieved if each point in a river section } \\
\text { is different from all other points within one } \mathrm{m}^{2} \text {. Structural elements would mainly be deadwood. In the best case, around } 15 \% \text { of the area would } \\
\text { be covered by deadwood. If there is more deadwood, the situation deteriorates, so the value function is an optimum curve. The worst-possible } \\
\text { case of } 100 \% \text { deadwood coverage is a theoretical value, which could occasionally occur after storm events. Optimal values are achieved for } \\
\text { up to } 70 \% \text { of the area being covered with deadwood. }\end{array}$
\end{tabular}

Dispersal:

drift /

benthos ratio

Substrate

armoring

(colmation)

for vertical

refugia

\section{Proportion of softw-BP}

softwood

vegetation/

length

Area of

softwood

vegetation/

length

Proportion of

hardwood

vegetation/

length

Proportion of

pioneer

vegetation/

length

hardw

pionveg driftbenthos There are quite good data for this in the literature. The relationship is certainly not linear, and there is an optimum at ca. $1-3 \%$ benthos being in drift. Around the optimum, the curve should be fairly flat. If there are around $4-5 \%$ of benthos in drift, the river is already in a fairly bad state, the worst-possible state is if $10 \%$ of benthos (or more) are in drift. For the increasing branch of the curve, if no benthos are in drift, the value is around 0.65 .

colm The worst-possible case is that the entire interstitial space is clogged with fine sediments $($ value $=0)$. Although the simplest relationship would be linear, BioC thinks that it is better to place the mid-point at around $60 \%$. If there is already a good ecological level, it is ecologically more valuable to improve this to a really good state. In contrast, if the river is in a bad state, the overall value of improving the river to a medium state is not so important. However, this is also a philosophical question: does one want to improve a heavily modified (urban) river? For BioC it is more important to improve a river towards a near-natural state. The shape is sigmoid, with the steepest slope around the middle. On a logarithmic scale it would be a linear relationship.

softw-BP It is important to consider the dimensions of the system. A small creek will not have more than $5-10 \mathrm{~m}^{2}$ of softwood per meter of river length, but a large river might have hundreds. Therefore, BioPhys proposes to use the ratio between area of softwood vegetation and area of wetted channel (per meter of river length). It is difficult to define the natural river for a Wigger-type river in Switzerland, because one does not have a natural state anymore. In the interview it was defined that "best-possible state" equals what can actually be achieved in Switzerland today with best-possible restoration measures.

softw-BB The calculation for the maximum value is based on $40 \mathrm{~m}$ from the river edge into the land-area (at a right angle to the river) and ca. $1 \mathrm{~km}$ length along the river: $40 \mathrm{~m} \times 1,000 \mathrm{~m}=40,000 \mathrm{~m}^{2} / \mathrm{km}=40 \mathrm{~m}^{2} / \mathrm{m}$.

Same comment as for softwood vegetation above.

Same comment as for softwood vegetation above; the numbers are the same as for softwood vegetation. 


\begin{tabular}{|c|c|c|}
\hline Attribute & Abbreviation & Comments \\
\hline $\begin{array}{l}\text { Proportion of } \\
\text { gravel bars/ }\end{array}$ & gravel-BP & ent as for softwood vegetation above. \\
\hline
\end{tabular}

gravel bars/
length

Area of

gravel bars/

gravel-BB

length

Natural benthos

benthic

organisms scrap

proportion of

scrapers

Relative

proportion of

shredders

Relative

proportion of

predators shred See comment to scrapers; optimum at around $20 \%$ shredders. Shredders are deadwood, leaf etc. devourers. In water bodies of $4^{\text {th }}$ order, lots of leaves enter the water bodies. If there are less than $20 \%$ shredders (of all benthos), this is not very good, it is an indication that the riparian vegetation and woods are missing. If there are more, this is indicative of shading due to riparian vegetation and woods. It is also an indicator of straightening of the river and lots of leaves entering the system. The maximal value can never be $100 \%$ because half of the benthos will be the next-following member in the succession chain, which are filterers and collectors-gatherers. If the maximum of around $40 \%$ shredders is reached, the river is not really in a bad state, so it receives a value of 0.5 .

See comment to scrapers. Predators are an interesting case. The other benthos change along the length of the river, but predators always have a maximum of ca. $10-15 \%$; more is not possible. The reason is that from one trophic level to the next there is a reduction of $90 \%$. If there are less than $10-15 \%$ predators, this means that there are fewer long-lived organisms, which is indicative of instable conditions. This can be caused by the load of fine sediments, by pollution, or by hydropeaking due to power stations. Theoretically, there can be zero predators, for instance if the oxygen conditions are really bad. 


\begin{tabular}{lll}
\hline \hline Attribute & Abbreviation & Comments \\
\hline $\begin{array}{l}\text { Relative } \\
\text { proportion of }\end{array}$ & collgath & $\begin{array}{l}\text { See comment to scrapers; optimum at around 20\% collectors-gatherers (of all benthos), the maximum is 50\% collectors-gatherers. They can } \\
\text { never reach 100\%. They are an indicator that a lot of detritus is introduced into the system. If there is substantially less than 20\% this is also a } \\
\text { collectors- } \\
\text { gatherers }\end{array}$ \\
$\begin{array}{l}\text { bad sign and means that there is hardly any nutrition for this group, i.e. crushed or shredded material. The decreasing branch from } 20 \text { to } 50 \% \\
\text { is rather typical and indicates that there is a diffuse input of material, while the increasing branch is untypical. }\end{array}$
\end{tabular}

Relative filter
proportion of

filterers

Relative proportion of periphyton

Seasonally averaged density of periphyton

\section{Reti-index:} (scrapers + wood-eaters + shredders)/ all feeding

types

F13

Yoshimuraindex: (scrapers + filterers)/

(shredders +
See comment to scrapers; optimum at around $20 \%$ filterers. This corresponds to the fourth order in the "river-continuum concept". Theoretically the proportion of filterers can reach $90-100 \%$. In contrast to collectors and gatherers, the filterers are capable of feeding on diffuse input material. Nevertheless, high values of $90-100 \%$ are rather theoretical. Zero filterers are a special case if there is acidification and no fine material, and thus no nutrition. This is indicative of a diffuse load.

periph-BA Theoretically, the relative proportion of periphyton concerns the production, but it is difficult to measure in practice. One would have to also measure the production of macrophytes and phytoplankton, which is difficult. The average value of periphyton is difficult to determine, and it strongly depends on the river type. However, there are a lot of good measurements available for this indicator. The shape is an optimum-curve. If there is few periphyton, this is an indicator of strong shading due to straightening of the river, or toxic substances in the water, or similar. If there is a lot of periphyton, there is no shading of the river, which indicates that there is a large distance from the river to the riparian vegetation. The optimum is around $50 \%$.

periph-BB Benthos diversity depends strongly on the river type and can be different for different rivers. According to the river-continuum-concept, you would have more shredders, the higher up you are (i.e. in the wooden zones); the nearer you are to the river, the more filterers and periphyton you would have. But the Wigger is not fringed by riparian forest. BioB would need all the benthos feeding groups, but cannot give values; it is fine to use the value functions from BioA. Periphyton is measured as ash free dry biomass (AFDM)/ $\mathrm{m}^{2}$; there is an optimum at around $100 \mathrm{~g}$ $\mathrm{AFDM} / \mathrm{m}^{2}$ in summer; but BioB is not sure about the numbers.

reti-index The Reti-index was developed for smaller rivers and is appropriate for rivers up to the $4^{\text {th }}$ order, i.e. such as the Wigger. It assesses the relative proportion of the most-important feeding groups for a Wigger-type river. It cannot increase to $100 \%$ because there are follow-organisms. The best-possible state is at around $40-50 \%$ of scapers, wood-eaters, and shredders. If there are fewer, there will be many filterers, and sediment loads or impacts of other substances. An improvement in the Reti-index always reflects a more-natural state of the river.

\section{F13-index}

The F13-index from Yoshimura et al. (2006) is also well suited to assess $4^{\text {th }}$ order water bodies such as the Wigger. BioA calculated a few examples. Optimum (near-natural river): $(30 \%$ shredders $+20 \%$ filterers $) /(20 \%$ shredders $+20 \%$ collectors-gatherers $)=1.25$. Worst-case river: $(5 \%$ scrapers $+10 \%$ filterers $) /(40 \%$ shredders $+30 \%$ gatherer-collectors $)=0.214$. Another bad example with no riparian vegetation, and lots of fine sediments: ( $5 \%$ scrapers $+10 \%$ filterers $) /(0 \%$ shredders $+70 \%$ gatherer-collectors $)=0.214$. A value of zero is hardly possible because this would mean that all feeding groups are reduced to zero. In reality, however, they would be replaced by other feeding groups. As the calculations demonstrate, to get a low value of the F13-index, different causes are possible. Therefore, BioA prefers an individual 


\begin{tabular}{|c|c|c|}
\hline Attribute & Abbreviation & Comments \\
\hline $\begin{array}{l}\text { gatherer- } \\
\text { collectors) }\end{array}$ & & $\begin{array}{l}\text { assessment of the different feeding groups (which is required anyway to be able to calculate the index). This increases transparency and helps } \\
\text { to evaluate the causes of a problem, while the causes are easily masked when using an index. }\end{array}$ \\
\hline $\begin{array}{l}\text { Natural } \\
\text { diversity of } \\
\text { macro- } \\
\text { invertebrates }\end{array}$ & macroinvert & $\begin{array}{l}\text { BioA would not use the diversity of macroinvertebrates as indicator; one would have to state exactly, which level one is assessing (species- } \\
\text { level, genus-level?). Experience concerning diversity valuations is not so good; diversity can strongly fluctuate, is dependent of the season, } \\
\text { amongst many other factors. Hence, even if diversity of macroinvertebrates is theoretically important, in practice it is not a very useful indicator. }\end{array}$ \\
\hline $\begin{array}{l}\text { Natural } \\
\text { diversity of } \\
\text { macro- } \\
\text { invertebrates }\end{array}$ & macrinv-BP & $\begin{array}{l}\text { BioPhys cannot give value functions for benthic organisms. One should use either the feeding groups or an index (not both). With respect to } \\
\text { scrapers there is a certain overlap with primary production, which feeds the scrapers, but it is not the only thing that affects scrapers. BioPhys } \\
\text { would prefer an assessment of the different feeding groups to an index. He gave a (linear) value function for the diversity of macroinvertebrates, } \\
\text { for which he suggests using the Shannon Weaver index } \mathrm{H}^{\prime} \text {, where } \mathrm{S} \text { is the total number of species and } \mathrm{p}_{\mathrm{i}} \text { is the frequency of the } \mathrm{i}^{\text {th }} \text { species } \\
\text { (probability that any given individual belongs to the species, hence } \mathrm{p} \text { ). } \\
H^{\prime}=-\sum_{i=1}^{S}\left(p_{i} \ln p_{i}\right)\end{array}$ \\
\hline $\begin{array}{l}\text { Natural } \\
\text { diversity of } \\
\text { macro- } \\
\text { invertebrates }\end{array}$ & macrinv-BB & $\begin{array}{l}\text { The diversity of the macroinvertebrates can substitute the other benthos feeding groups and can be used as attribute instead. The value function } \\
\text { increases: the more diversity the better. It is possible to use any diversity index. }\end{array}$ \\
\hline $\begin{array}{l}\text { Mean density } \\
\text { of ground } \\
\text { beetles }\end{array}$ & grbeetl & $\begin{array}{l}\text { BioA assessed ground beetles in his PhD; he found differences to other assessments, but these are mainly caused by more nutrient-rich or } \\
\text { nutrient-poor rivers. However, this objective should not be used to assess the nutrient content of the river, but rather whether the shoreline is } \\
\text { in a natural state. Ultimately, the more beetles, the better. There is also an extreme variance, depending on the season, the spot, etc. The } \\
\text { relationship is not linear. It is a combination of nutrient richness, the proportion of near-natural shorelines, and aquatic-terrestrial interactions. } \\
\text { If the latter alone were accessed, the relationship would be linear, but the nutrients cause an exponential value function. The maximum value } \\
\text { is reached at about ten individuals per } \mathrm{m}^{2} \text { and stays there for up to } 50 \text { individuals } / \mathrm{m}^{2} \text {. }\end{array}$ \\
\hline $\begin{array}{l}\text { Mean density } \\
\text { of rove } \\
\text { beetles }\end{array}$ & rovbeetl & $\begin{array}{l}\text { The density of rove beetles is highest when the flooding regime is (near-)natural. This equals around four individuals } / \mathrm{m}^{2} ; \text { the more, the better. } \\
\text { Variability is very high and depends on river type. Effects of morphology and habitat quality are not so strong. Shape of the value function is } \\
\text { very similar to that of ground beetles. }\end{array}$ \\
\hline $\begin{array}{l}\text { Natural fish } \\
\text { diversity, } \\
\text { lower } \\
\text { reaches } \\
\text { Wigger } \\
\end{array}$ & fish_low & \\
\hline $\begin{array}{l}\text { Total } \\
\text { biomass of } \\
\text { trout }\end{array}$ & totbiomasst & $\begin{array}{l}\text { Salmo trutta. The value function is steeper if the river is in a bad state, because it is more important to improve the river if it is in a bad state } \\
\text { than when it is already in a good state. The maximum in lower reaches is at around } 250 \mathrm{~kg} / \mathrm{ha} \text {. }\end{array}$ \\
\hline
\end{tabular}


Langhans SD, Lienert J (2016) Non-valid MCDA Simplifications. Plos One Supporting Information.

\begin{tabular}{lll}
\hline \hline Attribute & Abbreviation & Comments \\
\hline $\begin{array}{l}\text { Number of } \\
\text { young of the } \\
\text { year trout }\end{array}$ & YOYt & The young of the year are an indicator of natural reproduction. The value function is steeper when the river is in a bad state. \\
$\begin{array}{l}\text { Number of } \\
\text { juvenile trout } \\
\begin{array}{l}\text { Total } \\
\text { biomass of } \\
\text { adult trout }\end{array}\end{array}$ & juvent & $\begin{array}{l}\text { The juvenile trouts are the rest of the young trouts, i.e. without young of the year. Again, the value function is steeper when the river is in a } \\
\text { bad state. }\end{array}$ \\
$\begin{array}{lll}\text { Total } \\
\text { It is easier to assess the biomass of adults ( } \mathrm{kg} / \mathrm{ha}) \text { than to count individuals. The value function is steeper when the river is in a bad state. }\end{array}$ \\
\hline
\end{tabular}

adult barbel

and/ or chub

Number of

young of the

YOYb

year barbel

Number of

juvenile

barbel and/

or chub

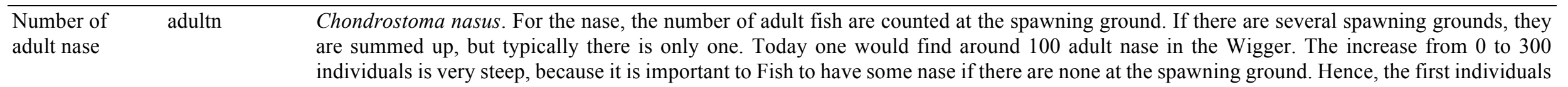
are very valuable.

Occurrence YOYn The young of the year nase are a very difficult attribute, and Fish thinks that there are no experts who could give a value function. The question of young of is how to measure them. Additionally, in the Wigger they wander into the river Aare. However, if they do occur in the Wigger, it is very special. the year nase Therefore, the Fish-expert decided that two (yes/ no) classes for occurrence would best reflect this. One could, additionally, assess the occurrence in additional classes (sporadic, numerous), but the occurrence alone suffices.

Total totbiomasssp Albumoides bipunctatus. The Wigger has a rather low density of spirlin, typically, one does not find many. The juvenile spirlin were not

biomass of assessed separately in the lower reaches, it is sufficient to have the total biomass of spirlin.

spirlin

Dominance domin In the Wigger it would be barbel (Barbus barbus) or chub (Leuciscus cephalus) that could dominate, both in the lower and the mid-reaches. In of any fish the lower reaches it could theoretically also be stoan loach (Barbatula barbatula), but this species does not have any weight compared to the species other two species. If it were to be included, one would have to use another measure than $\mathrm{kg} / \mathrm{ha}$. 
Langhans SD, Lienert J (2016) Non-valid MCDA Simplifications. Plos One Supporting Information.

\begin{tabular}{|c|c|c|}
\hline Attribute & Abbreviation & Comments \\
\hline $\begin{array}{l}\text { Number of } \\
\text { non-site- } \\
\text { specific } \\
\text { species }\end{array}$ & nonsite & $\begin{array}{l}\text { Some fish can enter the lower reaches that do not really belong there. The values and range should be the same as in the middle reaches. The } \\
\text { maximum would be around ten non site-specific species. }\end{array}$ \\
\hline $\begin{array}{l}\text { Percent fish } \\
\text { with } \\
\text { anomalies or } \\
\text { injuries }\end{array}$ & anom & $\begin{array}{l}\text { One would compare the percentage of fish with anomalies or injuries to all fish. The maximum of } 50 \% \text { is an extreme value that is hardly } \\
\text { reached in reality (but is possible). There is a very strong decrease in value in the beginning, i.e. if one finds the first few fish with anomalies } \\
\text { or injuries. }\end{array}$ \\
\hline $\begin{array}{l}\text { Natural fish } \\
\text { diversity, } \\
\text { mid reaches } \\
\text { Wigger }\end{array}$ & fish_mid & \\
\hline $\begin{array}{l}\text { Total } \\
\text { biomass of } \\
\text { trout }\end{array}$ & totbiomasstm & $\begin{array}{l}\text { Salmo trutta. Trout in mid-reaches is identical to head waters. It is still the dominant fish species. Additional indicators are barbel and a small } \\
\text { fish species: stone loach. }\end{array}$ \\
\hline $\begin{array}{l}\text { Number of } \\
\text { young of the } \\
\text { year trout }\end{array}$ & YOYtm & Identical to head waters. \\
\hline $\begin{array}{l}\text { Number of } \\
\text { juvenile trout }\end{array}$ & juventm & Identical to head waters. \\
\hline $\begin{array}{l}\text { Total } \\
\text { biomass of } \\
\text { adult trout }\end{array}$ & adbiomasstm & Identical to head waters. \\
\hline $\begin{array}{l}\text { Total } \\
\text { biomass of } \\
\text { barbel }\end{array}$ & totbiomassbm & $\begin{array}{l}\text { Barbus barbus. If number of attributes is to be kept as small as possible, it suffices to assess total biomass of barbel. It is not necessary to assess } \\
\text { biomass of adult barbel separately, since this is more or less the same. Rationale: total biomass of barbel is dominated by adult barbell and } \\
\text { barbel are a migrating species. }\end{array}$ \\
\hline $\begin{array}{l}\text { Number of } \\
\text { young of the } \\
\text { year barbel }\end{array}$ & YOYbm & $\begin{array}{l}\text { Barbel is a migrating species. The young barbels are very small and rather difficult to catch. Therefore, abundance is a difficult measure; they } \\
\text { don't gather in swarms. The time of the measure is important. You would have to carry it out in autumn, for instance September. The populations } \\
\text { are not that large. }\end{array}$ \\
\hline $\begin{array}{l}\text { Number of } \\
\text { juvenile } \\
\text { barbel }\end{array}$ & juvenbm & Without young of the year (YOY). \\
\hline $\begin{array}{l}\text { Biomass of } \\
\text { stone loach }\end{array}$ & totbiomasslm & $\begin{array}{l}\text { Barbatula barbatula. This is a site-specific species, but not a very sensitive indicator. However, Fish needs to know whether they occur or not. } \\
\text { They should not be massively abundant. }\end{array}$ \\
\hline
\end{tabular}


Langhans SD, Lienert J (2016) Non-valid MCDA Simplifications. Plos One Supporting Information.

\begin{tabular}{|c|c|c|}
\hline Attribute & Abbreviation & Comments \\
\hline $\begin{array}{l}\text { Dominance } \\
\text { of any fish } \\
\text { species }\end{array}$ & dominm & $\begin{array}{l}\text { Compared with trout, i.e. in the middle reaches of the Wigger, the dominating species would be barbel (Barbus barbus), or chub (Leuciscus } \\
\text { cephalus). For this attribute it does not matter whether the dominating species is site-specific or not. Important is only that trout is not dominated } \\
\text { by another species. }\end{array}$ \\
\hline $\begin{array}{l}\text { Number of } \\
\text { non-site- } \\
\text { specific } \\
\text { species }\end{array}$ & nonsitem & To have ten non-site-specific species would be an extreme value. \\
\hline $\begin{array}{l}\text { Percent fish } \\
\text { with } \\
\text { anomalies or } \\
\text { injuries }\end{array}$ & anomm & \\
\hline $\begin{array}{l}\text { Natural fish } \\
\text { diversity, } \\
\text { head water } \\
\text { Wigger }\end{array}$ & fish_head & \\
\hline $\begin{array}{l}\text { Total bio- } \\
\text { mass trout }\end{array}$ & totbiomassth & Salmo trutta. In head waters, the "total biomass of trout" is the same as "total biomass of fish". \\
\hline $\begin{array}{l}\text { Number of } \\
\text { young of the } \\
\text { year trout }\end{array}$ & YOYth & The young of the year are an indicator of natural reproduction. The value function is steeper when the river is in a bad state. \\
\hline $\begin{array}{l}\text { Number of } \\
\text { juvenile trout }\end{array}$ & juventh & These are the remaining of the young trouts, i.e. without YOY. \\
\hline $\begin{array}{l}\text { Total bio- } \\
\text { mass of adult } \\
\text { trout }\end{array}$ & adbiomassth & It is easier to assess the biomass of adults $(\mathrm{kg} / \mathrm{ha})$ than to count individuals. \\
\hline $\begin{array}{l}\text { Percent fish } \\
\text { with } \\
\text { anomalies or } \\
\text { injuries }\end{array}$ & anomh & One would compare the percentage of fish with anomalies or injuries to all fish. \\
\hline
\end{tabular}




\section{References}

Langhans, S.D., Lienert, J., Schuwirth, N., Reichert, P., 2013. How to make river assessments comparable: A demonstration for hydromorphology. Ecological Indicators 32, 264-275.

LAWA, 2004. "Gewässerstrukturkartierung in der Bundesrepublik Deutschland - Übersichtsverfahren“; in German (Mapping the quality of water body structures in Germany - Overview procedures), Schwerin, Germany. ISBN 987-3-88961-249-6, http://www.lawa.de/, order number 300823 , accessed 22.12.2014.

Schälchli, U., 2002. Innere Kolmation - Methoden zur Erkennung und Bewertung; in German (Inner substrate clogging - Methods for detection and assessment), Fischnetz-Publication (Project 01/11), Eawag, Dübendorf, Switzerland. http://www.fischnetz.ch/content_d/publ/tp.htm, accessed 22.12.2014.

Strager, M.P., Fletcher, J.J., Yuill, C.B., Strager, J.M., 2000. Not in My Watershed! An Interactive Tool to Evaluate Land Use Changes on Stream Water Quality, Prodeedings of the ESRI International User Conference.

http://proceedings.esri.com/library/userconf/proc00/professional/papers/PAP663/p663.htm, accessed 22.12.2014.

USEPA, 2003. Developing water quality criteria for suspended and bedded sediments (SABS), Potential approaches, US EPA Office of Water, Office of Science and Technology, Draft, August 2003.

http://water.epa.gov/scitech/swguidance/standards/criteria/aqlife/pollutants/sediment/upload/2004_08_17_criteria_sediment_sab-discussionpaper.pdf, accessed 22.12.2014.

van der Nat, D., Schmidt, A.P., Tockner, K., Edwards, P.J., Ward, J.V., 2002. Inundation dynamics in braided floodplains: Tagliamento River, Northeast Italy. Ecosystems 5, 636-647.

Yoshimura, C., Tockner, K., Omura, T., Moog, O., 2006. Species diversity and functional assessment of macroinvertebrate communities in Austrian rivers. Limnology 7, 63-74. 